JAMP: Jurnal Adminitrasi dan Manajemen Pendidikan

Volume 2 Nomor 3 September 2019, Hal : 147-155

Tersedia Online di http://journal2.um.ac.id/index.php/jamp/

ISSN 2615-8574 (online)

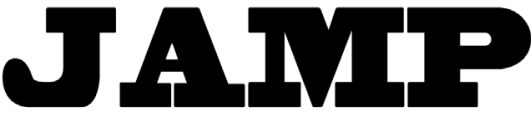

JURNAL ADMINISTRASI DAN MANAJEMEN PENDIDIKAN

\title{
MANAJEMEN PENDIDIKAN DAN PELATIHAN KEAHLIAN GANDA GURU SEKOLAH MENENGAH KEJURUAN
}

\author{
Ukhti Rochmawati \\ Agus Timan \\ Desi Eri Kusumaningrum \\ Universitas Negeri Malang, Jalan Semarang Nomor 5 Malang \\ Email: Ukhtircmwt18@gmail.com
}

\begin{abstract}
Research objectives to describe the management of education and training undertaken by the training institutions for the implementation of the program. Research using qualitative approach. The data collected by interview, observation, and documentation methods. Results of research: (1) program planning of multiple expertise PPPPPTK BOE Malang was start from an analysis of the needs of teachers, drafting the budget, recruitment of participants, to making proposals of activities; (2) organizing was done by the Division of proposals to work units, and continued by coordonation meeting for committee involement; (3) training implementation by using in-on-in model was done with provisioned speaker and attendees, and the strategies of andragogy approach. The implementation of the learning was begin with the opening to learning in each classroom; (4) evaluation of the implementation of the multiple expertise program at PPPTK BOE Malang was consist of participant's assesment, speaker of theacer's assesment, and organizer's assesment. .
\end{abstract}

Keyword: Educational and Training Management, Multiple Expertise

\begin{abstract}
Abstrak: Tujuan penelitian untuk mendeskripsikan manajemen pendidikan dan pelatihan yang dijalankan oleh lembaga pelatihan untuk pelaksanaan program keahlian ganda. Penelitian menggunakan pendekatan kualitatif. Data dikumpulkan dengan metode wawancara, observasi, dan dokumentasi. Hasil penelitian: (1) Perencanaan program keahlian ganda di PPPPPTK BOE Malang mulai dari analisis kebutuhan guru, penyusunan anggaran, perekrutan peserta pelatihan, sampai dengan pembuatan proposal kegiatan; (2) pengorganisasian dilakukan dengan pembagian proposal kepada unit kerja, dilanjutkan rapat koordinasi dan pelibatan ke dalam kepanitiaan; (3) model pelaksanaan pelatihan in-on-in dengan dilakukan pembekalan terhadap narasumber dan peserta dengan strategi pembelajaran pendekatan andragogi, kemudian pada pelaksanaan pelatihan diawali dengan pembukaan hingga pembelajaran di kelas masing-masing; (4) evaluasi pelaksanaan program keahlian ganda di PPPPTK BOE Malang menyangkut penilaian peserta, penilaian narasumber atau pengajar, dan penilaian penyelenggara.
\end{abstract}

Kata Kunci: Manajemen Pendidikan dan Pelatihan, Keahlian Ganda

Guru memiliki tanggung jawab yang sangat besar terhadap keberlangsungan proses pembelajaran di sekolah. Maka dari itu, guru dituntut untuk menguasai ilmu secara luas dan detail sehingga dapat mengajarkan secara maksimal. Menurut Undang-Undang Republik Indonesia Nomor 14 Tahun 2005 Pasal 1 tentang Guru dan Dosen mengatakan bahwa pendidik yang profesional mempunyai tugas utama yaitu mendidik, mengajar, mengarahkan, melatih, menilai dan mengevaluasi peserta didiknya mulai jenjang pendidikan usia dini hingga jenjang pendidikan menengah. Maka, sebuah kegiatan belajar mengajar akan terlaksana dengan baik jika guru memiliki kompetensi yang tinggi serta dapat menentukan kualitas pembelajaran. Dalam hal ini, guru yang memiliki kompetensi di bawah standar yang telah 
ditentukan, dapat mengikuti kegiatan pendidikan dan pelatihan yang diadakan oleh lembaga diklat dengan tujuan agar kompetensi yang dimiliki bisa meningkat. Pelatihan merupakan segala aktivitas yang dapat dirancang untuk meningkatkan kinerja atau potensi yang telah dimiliki oleh seseorang agar dalam melakukan pekerjaannya dapat lebih maksimal. Pelatihan juga menjadi salah satu mediator untuk menghadapi segala perubahan yang terjadi begitu cepat dan sebagai pendukung untuk bertambahnya kemampuan serta pengetahuan.

Pendidikan dan pelatihan harus dilakukan jika sekolah ingin memiliki guru yang kompetensinya tinggi dan sesuai dengan standar yang ditentukan. Menurut Daryanto \& Bintoro (2014) menyatakan bahwa diklat adalah sebuah proses yang terstruktur dan sistematis untuk mengembangkan pengetahuan, keterampilan serta sikap yang diperlukan seseorang untuk melaksanakan tugasnya yang diharapkan akan dapat mempengaruhi kinerja yang lebih baik dari orang tersebut, di tempat ia bekerja. Lembaga diklat tentunya mempunyai program yang akan membantu meningkatkan kualitas dan kompetensi yang dimiliki oleh guru sehingga guru akan mendapatkan bekal pengetahuan yang bertambah dan bisa diimplementasikan kepada peserta didiknya. Terdapat segenap usaha dari pihak pemerintah untuk membantu pemenuhan kewajiban guru serta meningkatkan kompetensi yang dimiliki dengan ekuivalen jam mengajar guru yang akan diperoleh. Selain jam mengajar yang pokok, guru akan diberi tugas tambahan yang harus dilaksanakan beriringan dengan tugas tambahan yang ada. Tugas tambahan tersebut mulai dari menjadi tutor paket A,B,C, kejuruan, pendidikan setara, menjadi guru bina pada sekolah terbuka, menjadi pembina kegiatan ekstrakurikuler yang ada di sekolah, menjadi guru inti, atau menjadi pemandu Musyawarah Guru Mata Pelajaran (MGMP), hingga menambah jam mengajar pada mata pelajaran lain (Agung, 2018). Penambahan jam mengajar untuk mata pelajaran lain bisa dilakukan guru agar memiliki kehalian ganda. Keahlian ganda yang dimaksudkan ialah keahlian tambahan yang dimiliki oleh guru selain keahlian utama yang biasa ia miliki. Misalnya, guru jurusan perangkat lunak diberikan pelatihan mengenai program keahlian ganda dan mengambil fokus di jurusan permesinan. Dengan begitu, jam mengajar guru tidak akan kurang dan akan menambah keahlian serta kompetensi pada diri guru itu sendiri.

Pelaksanaan program pelatihan keahlian ganda dilaksanakan dengan tujuan agar guru memiliki kompetensi baru atau keahlian baru yang berbeda dengan keahlian sebelumnya yang telah dimiliki. Pelatihan keahlian ganda in memberikan pelatihan untuk guru adaptif atau guru mata pelajaran agar memiliki keahlian di mata pelajaran lain. Misalnya, vguru mata pelajaran bahasa indonesia diikutkan program ini sehingga memiliki keahlian baru di mata pelajara otomotif atau lainnya. Sehingga pada saat terjadi kesenjangan pada jam mengajar akan bisa mengatasi. Program keahlian ganda mempunyai tujuan untuk pemenuhan dan penataan guru produktif SMK yang mendukung untuk peningkatan kualitas pendidikan vokasional dan pelatihan keterampilan kerja (Dewi, Dantes, \&Irawan: 2018).

Unit pelaksana teknis diklat adalah PPPPTK BOE Malang yang mempunyai tujuan untuk meningkatkan keahlian dan keterampilan yang dimiliki oleh guru agar standar kompetensi yang dimiliki setara dengan standar internasional. Dengan pelatihan yang diberikan diharapkan dapat menghasilkan tenaga pendidik dan kependidikan yang profesional dan mampu bersaing di era globalisasi modern. Lembaga ini melakukan pelatihan sesuai dengan kompetensi guru yang belum terpenuhi tentunya dengan cara mengadakan Uji Kompetensi Guru (UKG). Dengan tes tersebut, maka lembaga akan tahu dimana letak kekurangan guru dalam kegiatan pembelajaran dan tahu kompetensi mana yang akan ditingkatkan dengan proses manajemen yang terstruktur. Setelah dilakukan tes atau UKG, kemudian lembaga melakukan pemanggilan dengan cara pengiriman surat kepada sekolah yang guru nya perlu pelatihan, dan untuk proses pelaksanaan hingga evaluasi Dalam melakukan pelatihan, lembaga ini memiliki tema sesuai dengan indikator peningkatan kompetensi yang akan dicapai. Pada pelatihan yang dilaksanakan kali ini bertema Pelatihan Keahlian Ganda (PKG). Pelatihan ini bertujuan untuk meningkatkan keahlian yang dimiliki oleh guru menjadi dua bidang. Sebagai contoh, guru yang memiliki keahlian fisika, diberikan pelatihan bidang otomotif yang tujuannya agar guru tersebut dapat memiliki keahlian di luar bidang yang telah ia kuasai. Kenyataan di lapangan, ada beberapa sekolah yang memiliki kelebihan guru dalam mata pelajaran tertentu, sehingga adanya program ini membuat guru memiliki keahlian di bidang mata pelajaran lain selain mata pelajaran utama yang diajarkan. 
Tujuan penelitian ini adalah untuk mendeskripsikan manajemen pelatihan yang dilaksanakan oleh lembaga PPPPTK BOE Malang dengan sub fokus perencanaan diklat, pengorganisasian diklat, pelaksanaan diklat, dan evaluasi dari program diklat yang dilaksanakan. Pelaksanaan diklat akan terlaksana sesuai dengan tujuan yang telah dibuat jika lembaga mampu mengelolah program dengan efektif dan efisien.

\section{METODE}

Penelitian ini menggunakan pendekatan kualitatif dengan jenis penelitian studi kasus. Penelitian ini dilakukan di PPPPTK BOE Malang sebagai Unit Pelaksana Teknis (UPT) untuk pelaksanaan pelatihan. Teknik pengumpulan data pada penelitian ini adalah dengan wawancara secara mendalam, observasi lapangan, serta dokumentasi. Analisis data yang dilakukan bersamaan dengan proses pengumpulan data di lapangan. Dalam melakukan analisis data, peneliti mereduksi data yang diperoleh dari lapangan dengan cara memilih dan memilah setiap data yang sesuai dengan fokus penelitian, kemudian menyajikan data dalam bentuk teks narasi, gambar, serta tabel dan membuat kesimpulan pada masing-masing fokus penelitian. Pengecekan keabsahan data pada penelitian ini menggunakan teknik triangulasi (sumber/ teknik), pengecekan anggota (member check), perpanjangan waktu pengamatan, dan kecukupan bahan referensi.

\section{HASIL}

Pelaksanaan program pelatihan dan pendidikan atau diklat dilakukan karena adanya kebutuhan yang harus dipenuhi. Program pelatihan keahlian ganda untuk guru SMK dilakukan berdasarkan hasil dari analisis kebutuhan guru yang dilaksanakan oleh Direktorat Jenderal Guru dan Tenaga Kependidikan (Ditjen GTK) dan membuat Program Keahlian Ganda. kemudian melakukan perekrutan peserta pelatihan yang datanya diperoleh dari pusat dan diverisikasi untuk memastikan kecocokan datanya oleh Seksi DAI (Data dan Informasi) di PPPPTK BOE Malang.

Setelah melakukan analisis kebutuhan maka perencanaan selanjutnya ialah membuat anggaran kebutuhan yang dilakukan oleh seksi perencanaan bagian penganggaran kebutuhan. Dana yang diperoleh dari Pemerintah dikarenakan Program Keahlian Ganda termasuk program giving dan lembaga pelaksana teknis memetakan atau breakdown menjadi satuan biaya sesuai dengan aturan dan kebijakan yang dibuat oleh Menteri Keuangan. Penganggaran dibuat dengan menganut prinsip efektivitas dan efisiensi. Perencanaannya mulai dari anggaran untuk peralatan tulis kantor (ATK) yang digunakan untuk diklat, honor dari panitia, narasumber dan instruksinya, anggaran untuk sarana prasarananya, termasuk juga untuk anggaran konsumsi peserta dan semua pihak yang terlibat dalam pelaksanaan diklat Keahlian Ganda. Selanjutnya setelah anggaran telah dibuat dan disusun maka pembuatan proposal yang dilakukan oleh bagian program.

Pendistribusian proposal yang telah ditetapkan dan dilakukan pada semua unit kerja. Setelah itu dilakukan koordinasi mengenai proposal yang telah didistribusikan dan mempersiapkan kebutuhan apa saja yang nantinya akan digunakan pada saat pelaksanaan Program Keahlian Ganda. Setelah setiap unit kerja menerima informasi dari proposal, maka setiap departemen akan mempersiapkan program studinya masing-masing untuk merencanakan siapa yang akan menjadi narasumber sesuai dengan syarat dan ketentuan yang ada. Setelah itu, program studi akan membuat rancangan bahan ajar dan jadwal untuk kegiatan pelatihan dan pendidikan di kelas serta jadwal untuk pelaksanaan praktek kerja. Setelah sudah tersusun dengan baik, maka dilakukan rapat koordinasi yang membahas secara keseluruhan mengenai kesiapan dari data, peralatan, sarana prasarana, konsumsi dan termasuk juga anggarannya. Rapat dilakukan secara keseluruhan dengan Ketua Lembaga dan nantinya setiap departemen juga akan melakukan rapat koordinasi dengan anggotanya di program studi.

Struktur kepanitian dalam Program Keahlian Ganda terdiri dari beberapa susunan unit kerja yang berada di bawah Ditjen GTK yang terdiri dari tim daerah dan tim pusat. Ditjen GTK mempunyai peran dalam pembuatan program yang akan dilaksanakan seusia dengan analisis kebutuhan guru yang 
dilakukan oleh Dinas Pendidikan Kabupaten/Kota, kemudian PPPPTK BOE sebagai Unit Pelaksana Teknis (UPT) yang melaksanakan program Keahlian Ganda dan meluluskan pesertanya, kemudian Lembaga Sertifikasi Profesi (LSP) sebagai lembaga yang menangani sertifikasi guru yang dinyatakan lulus keahlian baru dan Lembaga Pendidik Tenaga Kependidikan (LPTK) sebagai pelaksana Pendidikan Profesi Guru (PPG). Kepala pusat memiliki peran sebagai pemberi keputusan atas perubahan yang terjadi. Pada saat proses pelaksanaan, setiap sesksi bagian akan terlibat dalam kegiatan dan melakukan koordinasi sesuai dengan tugas yang telah diberikan. Koordinasi yang sangat baik akan membuat pelaksaan menjadi sesuai dengan rencana diadakannya program.

Proses pelaksanaan diklat keahlian ganda di PPPTK BOE Malang diawali dengan pembekalan narasumber dan peserta Program Keahlian Ganda terdiri dari 40 orang perkelasnya dengan materi pelatihan mengenai informasi yang didapatkan pada pedoman dan jurnal teknis pelaksaanaan In Service Training, panduan kerja dalam pelaksanaan pelatihan, materi dasar program keahlian, dan model pembelajaran yang akan diberikan. Model pelatihan yang digunakan dalam pelatihan keahlian ganda dilakukan dengan model in-on-in. Maksudnya, pelaksanaan in pertama dilakukan di lembaga dengam memberikan awalan materi selama kurun waktu tertentu. Setelah itu tahap on, yaitu dilaksanakan di sekolah dari masing-masing peserta diklat dengan diawasi oleh kepala sekolah dan mentor yang telah ditunjuk. Pada tahap in ke 2, dilaksanakan di PPPPTK BOE. Strategi pembelajaran yang dilaksanakan selama dua minggu di PPPPTK BOE Malang menggunakan refleksi dan pendalaman modul serta pendalaman materi modul kompetensi keahlian, praktik kerja industri, penguatan dan uji kompetensi keahlian. Model pembelajaran yang digunakan dalam pelaksanaan diklat adalah dengan menerapkan pendekatan pendidikan orang dewasa (andragogi) yaitu melakukan interaksi antara widyaiswara dengan peserta ataupun pseserta dengan peserta. Hal ini dilakukan agar suasana kelas tidak kaku dan tidak membosankan. Strategi pembelajaran menggunakan model pendekatan ilmiah dengan pembelajaran berdasarkan masalah, proyek, dan desain. Ketika memasuki kelas, peserta melakukan pengisian daftar hadir disusul dengan apersepsi yang dilakukan oleh widyaiswara untuk mengingatkan kembali pembelajaran pada hari sebelumnya. Setelah apersepsi, narasumber menjelaskan materi yang akan disampaikan pada hari ini. Pada saat pelaksanaan, widyaiswara atau pengajar menggunakan metode dengan pendekatan ilmiah agar kerjasama antar peserta dan pengajar bisa menyatu dan tidak kaku. Pada saat pelaksanaan terdapat kendala yang terjadi pada peserta diklat, yaitu perbedaan pemahaman yang terjadi disetiap individu peserta. Sehingga ada peserta yang cepat dalam penyerapan materi ada juga yang lambat. Untuk mengatasi hal itu, maka widyaiswara memberikan waktu ekstra untuk peserta tersebut.

Proses evaluasi pelaksanaan diklat Keahlian ganda di PPPPTK BOE terdiri dari 3 bentuk pengevaluasian yang terdiri dari evaluasi peserta, evaluasi narasumber atau pengajar, dan evaluasi penyelenggara atau panitia. Evaluasi dilakukan untuk mengevaluasi peserta, narasumber atau pengajar, dan evaluasi untuk penyelenggara. Penilaian untuk peserta terdiri dari dua macam yaitu penilaian tes dan non-tes. Penilaian tes merupakan penilaian pre-test dan post-test yang dilakukan secara online dengan sistem yang telah disediakan, setelah itu nilai akan keluar pada format penilaian yang ada pada masing-masing narasumber atau pengajarnya. Penilaian pre-test dilakukan di awal pelaksanaan diklat untuk melihat dan mengetahui seberapa luas pengetahuan peseta untuk materi atau bahan ajar yang akan diajarkan pada saat kegiatan pelaksanaan pelatihan keahlian ganda. Pada penilaian non tes, aspek yang dinilai meliputi aspek sikap dan keterampilan, kemudian dilakukan rekapitulasi penilaian peserta oleh narasumber dari tes dan non-tes. Kemudian ada penilaian non-test yang meliputi penilaian sikap dan keterampilan dilakukan oleh pengajar dengan format yang telah diberikan oleh pusat yang terdiri dari berbagai aspek penilaian, termasuk aspek sikap dan keterampilan dari peserta pada saat mengikuti program diklat Keahlian Ganda.

Evaluasi merupakan bagian penting dari sebuah proses pelaksanaan suatu kegiatan. Menurut Wijaya, Yoto, \& Suhartadi (2018) pada kegiatan pengevaluasian kegiatan program keahlian ganda guru SMK akan digunakan untuk melihat peningkatan kompetensi yang dimiliki guru tersebut apakah sudah memenuhi standar yang telah ditentukan atau belum. Untuk evaluasi narasumber juga dilakukan oleh peserta untuk menilai bagaimana penyampaian narasumber dalam menyampaikan materi diklat 
sampai sikap dan keteraturan diri narasumber selama pelaksanaan diklat. Evaluasi untuk pengajar atau narasumber terdiri dari aspek yang dinilai diantaranya mengenai penyampaian materi yang disampaikan narasumber, sistematikanya dalam penyajian materi, kemudian metode pembelajarannya di kelas, pengajaran terhadap praktik yang diberikan, kedisiplinan dari narasumbernya, kerapihan pakaian hingga cara penyampaiannya yang memotivasi para peserta. Evaluasi narasumber dilakukan pada akhir kegiatan dengan format yang telah diberikan oleh pusat yang tertera pada jurnal teknis atau juknis pelaksanaan.

Evaluasi penyelenggara dilakukan sesuai dengan format yang diberikan oleh Pusat dengan berbagai aspek yang dinilai meliputi aspek kesesuaian program, layanan administrasi yang diberikan termasuk juga konsumsi dan transportasinya, kesesuaian dari kegiatan pembelajarannya bagaimana, dan fasilitas penunjang yang diberikan penyelenggara apakah memuaskan atau tidak. Setelah dilakukan proses penilaian yang dilakukan pada akhir pelaksanaan pelatihan untuk Program keahlian ganda dilakukan untuk mengetahui kekurangan yang terjadi selama program tersebut berlangsung. Apabila terjadi kekurangan maka lembaga akan mempelajari kesalahannya dan memperbaiki dengan cara menganalisis hasil dari penelialaian yang diberikan. Untuk evaluasi dari peserta, jika ada kekurangan yang terjadi selama pelaksanaan atau tidak memenuhi persyaratan kelulusan untuk program pelatihan, maka akan diberikan waktu tambahan. Untuk penyelenggaraan jika terjadi kekurangan, maka akan diperbaiki untuk pelaksanaan program selanjutnya agar pelatihan lebih efektif dan mampu memberikan hasil yang memuaskan untuk peserta ataupun pelaksana.

\section{PEMBAHASAN}

Perencanaan berisi perumusan dari tindakan-tindakan yang dianggap perlu untuk mencapai tujuan yang diinginkan sesuai dengan maksud dan rencana yang telah ditetapkan. Perencanaan pada umumnya dapat dikatakan sebagai keputusan terhadap hal yang akan dilakukan kemudian hari. Pada proses perencanaan terdapat tahapan menurut Herlina, Hidayat, \& Djumena (2017) yaitu penyusunan kebutuhan atau identifikasi kebutuhan, penyusunan tujuan pelaksanaan pelatihan, penentuan instruktur, rekrutmen, penentuan kurikulum, penentuan sumber belajar, dan penentuan waktu pelaksanaan Tujuan utama dari perencanaan pelatihan adalah mengidentifikasi kebutuhan yang dibutuhkan pada pelatihan. Kegiatan perencanaan diklat Program Keahlian Ganda untuk guru SMK diawali dengan analisis kebutuhan yang dilakukan oleh Pemerintah Pusat atau Ditjen GTK (Guru dan Tenaga Kependidikan). Analisis kebutuhan dilakukan untuk mengetahui bagaimana keadaan yang terjadi di lapangan dan apa yang sedang menjadi kebutuhan guru di Indonesia. Setelah dilakukan analisis, maka ditemukan kesenjangan yang sedang terjadi dan membuat program yang sesuai kebutuhan untuk mengatasinya. Mulyasa (2009) berpendapat bahwa perencanaan merupakan proses yang sistematis dalam pengambilan keputusan tentang tindakan yang akan dilakukan pada waktu yang akan datang. Perencanaan merupakan strategi untuk mencapai suatu tujuan yang dibuat sebelum melakukan suatu tindakan, membuat program, dan kegiatan. Hal ini sesuai dengan perencanaan yang dilakukan oleh pemerintah Pusat yaitu setelah menganalisa kebutuhan maka pembuatan program, dilakukan untuk mengatasi kesenjangan yang terjadi.

Setelah Pemerintah rancangan program, maka program tersebut dilimpahkan kepada Unit Pelaksana Teknis PPPPTK BOE Malang yang kemudian mempelajari jurnal teknis yang diberikan. Penganggaran dilakukan oleh Seksi Perencanaan bagian penyusun anggaran yang membuat perencanaan anggaran yang sesuai dengan kebutuhan. Di dalam anggaran akan dibuat kerangka kebutuhan yang termasuk anggaran untuk ATK (Alat Tulis Kerja) yang digunakan untuk peserta, pengajar maupun penyelenggaranya, terdapat juga mengenai honorarium yang terlibat dalam penyelenggaraan, transportasi dari peserta, bahan ajar dan modul, termasuk juga sarana prasarana yang dibutuhkan. Menurut Daryanto \& Bintoro (2014) butuh banyak biaya yang harus dikeluarkan. Agar dapat berlangsung secara efektif dan efisien, maka perlu diatur sedemikian rupa. Kegiatan analisis kebutuhan ini merupakan kegiatan dalam memilih dan memilah antara ketidaksesuaian dengan kesenjangan performa yang kurang dengan kemampuan yang diharapkan oleh tuntutan pekerjaan mereka. Dengan demikian, proses penganggaran yang dilakukan oleh PPPPTK BOE mengacu pada satuan biaya dan disesuaikan dengan rincian rencana kegiatan dan kebutuhan untuk pelaksanaan Program Keahlian Ganda. 
Perekrutan peserta diklat yang datanya diperoleh dari pemerintah dengan melihat data dari uji kompetensi yang dilakukan pada tahun 2015. Kemudian yang telah diverifikasi oleh Dinas Pendidikan Kabupatan/Kota dengan kuota yang sudah ditentukan. Kemudian pihak Dinas Pendidikan memverifikasi data yang telah diinput oleh sekolah dan disetujui oleh pihak Ditjen GTK. Kemudian lembaga pelatihan menerima data calon peserta dan akan melakukan menyocokan data peserta dan melakukan pemanggilan dengan cara menyebarkan undangan. Hal ini sesuai dengan hasil penelitian Dariyanto (2014) yang menyebutkan bahwa proses perekrutan calon peserta pelatihan Kurikulum 2013 di PPPPTK PKn dan IPS berdasarkan dari data-data yang diajukan oleh Dinas Pendidikan pada masing-masing daerah yang ada di Jawa Timur. Perekrutan peserta pelatihan ditentukan dengan kuota yang didapatkan dari Pemerintah sebanyak 46.441 peserta yang diperoleh lembaga dari apikasi verval (verifikasi dan validasi). Data-data yang diperoleh kemudian dikirimkan ke Jakarta untuk diverifikasi dan validasi oleh Kementrian Pendidikan dan Kebudayaan. Selanjutnya data nama guru yang lolos verifikasi akan melatih pada pelatihan Kurikulum 2013 bagi guru sasaran, data tersebut akan diunggah oleh Kemendikbud ke aplikasi manajemen (verval), untuk selanjutnya dipetakan sesuai daerah masing-masing, PPPTK PKn dan IPS khusus menangani peserta dari guru-guru jenjang SMP. Selanjutnya adalah pembuatan proposal yang akan dilakukan oleh bagian Seksi Program sesuai dengan anggaran kebutuhan yang telah direncanakan dan melihat jumlah peserta yang akan mengikuti pelaksanaan program diklat Keahlian ganda di PPPPTK BOE Malang yang sesuai dengan jurnal teknis yang diberikan oleh Pemerintah Pusat sebagai pembuat progam pelatihan.

Tahap selanjutnya adalah pengorganisasian setelah diadakannya perencanaan. Pengorganisasian yang dilakukan PPPPTK BOE Malang dalam Program Keahlian Ganda yaitu pendistribusian proposal kepada setiap unit kerja. Setelah proposal sudah dibuat oleh bagian program, maka proposal tersebut di didtribusikan kepada setiap departemen dan program studi yang ada di PPPPTK BOE Malang. Pendistribusian ini dilakukan untuk memberikan informasi apa yang harus dilakukan setiap unit dalam pelaksanaan diklat Keahlian Ganda dengan tugas dan tanggung jawab yang telah diberikan sesuai jurnal teknis pelaksanaan oleh pemerintah. Menurut Herujito (2004) yaitu: (1) prinsip perumusan tujuan secara jelas dan tepat; (2) prinsip pembagian pekerjaan; (3) prinsip kontinuitas dan fleksibilitas; (4) prinsip delegasi wewenang dan tanggung jawab; (5) prinsip kesatuan arah; (6) prinsip kesatuan komando; (7) prinsip rentangan kekuasaan; (8) prinsip tingkatan pekerjaan; dan (9) prinsip koordinasi. Pengorganisasian di PPPPTK BOE menggunakan prinsip koordinasi. Setiap seksi bagian yang terlibat akan saling berkoordinasi untuk pemenuhan kebutuhan untuk pelaksanaan diklat keahlian ganda ini. Pengorganisasian dalam diklat keahlian ganda dikoordinasikan oleh Ditjen GTK yang terdiri dari Tim Pusat dan Tim Daerah. Ditjen GTK mempunyai peran dalam pembuatan program yang akan dilaksanakan sesuai dengan analisis kebutuhan guru yang dilakukan oleh Dinas Pendidikan, kemudian PPPPTK BOE sebagai Unit Pelaksana Teknis (UPT) yang melaksanakan program Keahlian Ganda dan meluluskan pesertanya, kemudian Lembaga Sertifikasi Profesi (LSP) sebagai lembaga yang menangani sertifikasi guru yang dinyatakan lulus keahlian baru dan Lembaga Pendidik Tenaga Kependidikan (LPTK) sebagai pelaksana PPG guru tersebut.

Dalam pengorganisasian di PPPPTK BOE Malang terdapat tiga tim yang menjadi kepanitian dalam pelaksanaan diklat Keahlian Ganda ini yang terdiri dari: 1) Penanggungjawab Bidang Akademik (PJBA), 2) Tim Teknis, dan 3) Panitia Kelas yang masing-masing sudah mempunyai tugas dan tanggung jawab yang tertulis pada pedoman pelaksanaan. Untuk pemilihan panitia dalam pelaksanaan ditentukan berdasarkan konpetensi yang dimiliki sesuai dengan persyaratan yang ada. Kepala Pusat sebagai pengambil keputusan dan pemberian komando atas apa saja yang harus dilakukan sesuai dengan juknisnya. Kesamaan dari hasil penelitian oleh Dariyanto (2014) tentang perorganisasian yang menyatakan bahwa pengaturan struktur kepanitiaan dalam pelatihan Kurikulum 2013 secara besar terdiri dari beberapa susunan kerja dari pemerintahan pusat hingga unit-unit kerja pelaksana teknis di bawah pemerintahan daerah. Selain itu, untuk susunan kepanitian pelaksana di PPPPTK PKn dan IPS juga terdiri dari tiga tim yaitu tim pelaksana bidang akademi, tim teknis dan panitia kelas. Pengaturan kepanitian dilaksanakan berdasarkan ketentuan dan persyaratan sesuai dengan aturan yang terdapat pada jurnal teknis. 
Pelaksanaan pelatihan pada dasarnya adalah mempertemukan antara fasilitator dan peserta yang dibatasi oleh kurikulum, metode, dan ditunjang oleh sarana dan prasarana yang ada serta legalitas dan sumber pendanaan (Sonhaji, 2001). Salah satu model yang bisa digunakan sebagai landasan untuk menancapkan materi pelatihan ke dalam memori jangka panjang peserta pelatihan adalah model pemrosesan informasi menurut teori belajar kognitif. Model tersebut menstimulisasi materi yang diberikan dan akan melekat pada ingatan dari peserta pelatihan agar informasi yang didapat bisa diingat kembali (Sultoni, 2016). Pelaksanaan pelatihan Program Keahlian Ganda di PPPPTK BOE Malang dilakukan dengan model in-on-in. Dengan peserta diklat yang berasal dari seluruh sekolah SMK yang ada di Indonesia. Pelaksanaan diawali dengan pembukaan pra pelaksanaan yang dilakukan untuk menyampaikan seluruh informasi dan kebijakan yang ada dari pusat sesuai dengan pedoman pelaksanaan pelatihan. Narasumber dan peserta diberikan pembekalan secara terpisah dengan masing-masing kelas berisi 40 orang dengan penyampaian panduan kerja dalam pelaksanaan pelatihan, materi dasar program keahlian, dan model pembelajaran yang akan diberikan. Pelaksanaan Program Keahlian Ganda diawali dengan pembekalan bagi peserta dan mentor. Pada On Service Training, peserta dengan bimbingan mentor mempelajari materi program keahlian selama 12 minggu secara daring kombinasi dan mengikuti tes akhir pada materi program keahlian yang dipelajari saat $O n$.

On Service Training merupakan tahap kegiatan awal dari pelaksanaan Program Sertifikasi Keahlian dan Sertifikasi Pendidik bagi Guru SMK/SMA (Keahlian Ganda). Peserta selama mengikuti kegiatan ini akan mendapatkan pengenalan dan pendalaman kompetensi guru produktif serta pendalaman materi program keahlian sesuai capaian pembelajaran. Kegiatan ini dilaksanakan menggunakan model daring kombinasi selama 3 (tiga) bulan atau 12 (dua belas) minggu yang bertempat di sekolah asal. Pada kegiatan ini, guru mempelajari materi secara mandiri dengan dibimbing oleh mentor yang sesuai dengan kompetensi keahlian yang dipelajari. Pada kegiatan ini, juga akan dilakukan penjaminan mutu oleh PPPPTK/LPPPTK KPTK. Tahapan setelah peserta melaksanakan On Service Training adalah pembelajaran tatap muka di PPPPTK BOE Malang In Service Learning. Model pembelajaran yang digunakan dalam pelaksanaan diklat Keahlian Ganda Guru SMK di PPPPTK BOE adalah dengan menerapkan pendekatan pendidikan orang dewasa (andragogi) yaitu melakukan interaksi antara widyaiswara dengan peserta ataupun pseserta dengan peserta. Hal ini dilakukan agar suasana kelas tidak kaku dan tidak membosankan. Strategi pembelajaran menggunakan model pendekatan ilmiah dengan pembelajaran berdasarkan masalah, proyek, dan desain.

Persamaan dalam pelaksanaan diklat Kurikulum yang dilakukan oleh Dariyanto (2014) yaitu strategi yang digunakan pengajar dalam melaksanakan penelitian adalah menggunakan pendekatan belajar andragogi dan konstruktivisme, hal ini seperti yang diungkapkan peneliti ketika mengamati kegiatan belajar mengajar di kelas. Terlihat pada saat pembukaan di kelas pengajar melakukan apersepsi dengan cara mengajak sharing dan pembelajaran dilakukan dengan membuat kelompok kecil di dalam kelas. Yoto (1997) yang mengatakan bahwa strategi merupakan cara untuk mencapai tujuan yang dapat meningkatkan dan mengembangkan sumber daya manusia. Setiap strategi pembelajaran mempunyai kekhususan masing-masing tergantung kebutuhan. Oleh karena itu setiap pengajar harus mampu menggunakan beberapa teknis dan pendekatan dalam pembelajara untuk mencapai tujuan pengajaran. Pembelajaran di dalam kelas diawali dengan pembukaan atau apersepsi oleh narasumber yang berguna untuk mengingatkan kembali materi yang disampaikan pada hari sebelumnya oleh peserta. Kemudian, pengajar akan memberikan materi pembelajaran yang sesuai dengan jadwal dan dilakukan dengan kombinasi metode pengajaran yaitu ceramah serta pemberin contoh agar penyerapan materi dapat dilakukan dengan mudah. Hal ini terlihat pada saat peneliti melakukan pengamatan di kelas. Pada kegiatan belajar mengajar di kelas, narasumber menjelaskan teori sedikit dan lebih banyak praktik dengan segala sarana prasarana yang disediakan kemudian narasumber secara langsung menjelaskan dengan membawa media yang ada.

Evaluasi pelatihan Program Keahlian Ganda di PPPPTK BOE Malang ada tiga bentuk pengevaluasian yang terdiri dari evaluasi untuk peserta, evaluasi untuk narasumber, dan evaluasi untuk penyelenggara. Evaluasi peserta terdiri dari pre-test, post-test dan non-test yang meliputi penilaian sikap dan keterampilan. Kemudian nilai tersebut dilakukan repitulasi untuk mengetahui lulus tidaknya peserta 
dalam program diklat Keahlian Ganda ini. Evaluasi untuk narasumber juga dilakukan guna untuk mengetahui apakah kinerja pengajar selama proses pembelajaran di kelas sudah sesuai dengan materi, apakah dalam penyampaiannya mudah diserap atau tidak, kemudian dari kerapihan pakaian. Untuk evaluasi penyelenggara, terdapat beberapa aspek yang harus dinilai. Peserta diminta untuk menilai fasilitas yang diberikan oleh lembaga, kinerjanya, bahan dan alat yang disediaakan. Penilaian dilakukan diakhir kegiatan dengan memberikan format-format penilaian, akan tetapi untuk penilaian secara tes dilakukan melalui sistem yang telah disediakan. Sejalan dengan hasil penelitian yang dilakukan oleh Lestari \& Ulfatin (2015) Evaluasi yang dilakukan untuk peserta digunakan untuk mengetahui pengetahuan yang didapatkan selama kegiatan pelatihan berlangsung. Bentuk evaluasi peserta anatar lain: pre test, tanya jawab, pengamatan selama kegiatan, nilai dari tugas yang diberikan, dan post test. Evaluasi terhadap fasilitator dilakukan untuk menilai kemampuan pengajar dalam memberikan materi, pembimbingan selama pelaksanaan, fasilitas dan melatih substansi materi pada peserta diklat, serta kinerjanya. Evaluasi program penyelengaraan diklat meliputi: pelayanan kesekretariatan, akomodasi, ruangan untuk proses pelaksanaan, sarana prasarana, suasana belajar, Alat Tulis Kantor (ATK) peserta dan panitia diklat; dan layanan untuk kesehatan.

Menurut Amtu (2013) penilaian merupakan proses pengawasan untuk pengendalian performa sekolah untuk memastikan bahwa jalannya penyelenggaraan kegiatan di sekolah telah sesuai dengan rencana yang telah ditetapkan. Adanya penilaian untuk peserta, narasumber, maupun penyelenggara dilakukan agar mengerti apa saja yang belum dapat terlaksana dan belum tercapai, maka dari itu penilaian sangat penting dilakukan oleh PPPPTK BOE Malang untuk mengetahui sejauh mana keberhasilan pelaksanaan program pelatihan keahlian ganda. Terjadi kesamaan hasil dengan penelitian yang dilakukan oleh Dariyanto (2014) yaitu pelatihan Kurikulum 2013 untuk guru SMP juga mempunyai format dari pemerintah dengan 3 aspek yang dinilai yakni peserta, narasumber, dan penyelenggara. Penilaian terhadap peserta dilakukan oleh narasumber dengan post-test. Tetapi terjadi perbedaan penilaian pada non tes, penilaian Kurikulum 2013 terdapat aspek kemampuan yang harus dinilai. Untuk pelatihan Keahlian Ganda aspek yang dinilai adalah prakteknya pada saat selesai pemberian teori. Hasil penelitian Dariyanto menyebutkan juga penilaian dilakukan peserta untuk narasumber dan penyelenggara sesuai dengan format yang telah diberikan pada pedoman pelaksanaan.

\section{SIMPULAN}

Tahapan dalam proses perencanaan diklat keahlian ganda diawali dengan analisis kebutuhan yang sedang terjadi di lapangan terhadap guru khususnya Guru SMK. Setelah didapatkan hasil dari analisis kebutuhan, maka dibuatlah Program Keahlian Ganda ini dengan langkah awal yaitu membuat anggaran untuk pelaksanaan oleh Seksi Perencanaan bagian Penganggaran Kebutuhan. Dana yang diperoleh dari Pemerintah dikarenakan program Keahlian ganda termasuk program giving dan lembaga pelaksana teknis memetakan menjadi satuan biaya sesuai dengan aturan dan kebijakan yang dibuat oleh Menteri Keuangan. Kemudian melakukan rekrutmen calon peserta pelatihan yang dilakukan oleh Pemerintah Pusat Ditjen GTK, kemudian pemilihan peserta diserahkan pada masing-masing sekolah diverifikasi oleh Dinas Kabupaten/Kota dan data peserta dilimpahkan pada Seksi bagian data dan Informasi (DAI) yang ada di PPPPTK BOE Malang. Setelah itu pembuatan proposal dibuat oleh seksi program yang mengacu pada jurnal teknis pedoman pelaksanaan Keahlian Ganda.

Pengorganisasian Pelatihan Keahlian Ganda di PPPPTK BOE Malang melibatkan beberapa susunan unit kerja yang berada di bawah Ditjen GTK yang terdiri dari tim daerah dan tim pusat. Ditjen GTK mempunyai peran dalam pembuatan program yang akan dilaksanakan sesuai dengan analisis kebutuhan guru yang dilakukan oleh Dinas Pendidikan, kemudian PPPPTK BOE sebagai Unit Pelaksana Teknis (UPT) yang melaksanakan program Keahlian Ganda dan meluluskan pesertanya, kemudian Lembaga Sertifikasi Profesi (LSP) sebagai lembaga yang menangani sertifikasi guru yang dinyatakan lulus keahlian baru dan Lembaga Pendidik Tenaga Kependidikan (LPTK) sebagai pelaksana PPG guru tersebut. Pengaturan panitia dilakukan sesuai dengan persyaratan dan kualifikasi yang telah ditentukan dalam pedoman pelaksanaan. 
Proses pelaksanaan diklat Keahlian Ganda di PPPTK BOE Malang diawali dengan pembekalan narasumber dan peserta program. Proses acara pembukaan pada pelaksanaan diklat Keahlian Ganda di PPPPTK BOE bertujuan untuk memberikan informasi kembali terkait hal-hal yang bersangkutan dengan diklat yang akan dilaksanakan, yang mungkin belum tersampaikan atau kurang jelas untuk peserta. Strategi pembelajaran pembelajaran yang dilaksanakan selama dua minggu di PPPPTK BOE Malang menggunakan refleksi dan pendalaman modul serta pendalaman materi modul kompetensi keahlian, praktik kerja industri, penguatan dan uji kompetensi keahlian. Model pembelajaran yang digunakan dalam pelaksanaan diklat adalah dengan menerapkan pendekatan pendidikan orang dewasa (andragogi) yaitu melakukan interaksi antara widyaiswara dengan peserta ataupun peserta dengan peserta. Kemudian dalam pembelajaran di kelas menggunakan pembelajaran model kombinasi dengan pelaksaan teori yang lebih sedikit dan banyak melakukan praktek.

Proses evaluasi pelaksanaan diklat keahlian ganda di PPPPTK BOE terdiri dari 3 bentuk pengevaluasian yang terdiri dari evaluasi peserta, evaluasi narasumber atau pengajar, dan evaluasi penyelenggara atau panitia. Penilaian untuk peserta terdiri dari dua macam yaitu penilaian tes dan non-tes. Penilaian narasumber aspek yang dinilai diantaranya mengenai penyampaian materi yang disampaikan narasumber, sistematikanya dalam penyajian materi, kemudian metode pembelajarannya di kelas, pengajaran terhadap praktek yang diberikan, kedisiplinan dari narasumbernya, kerapihan pakaian hingga cara penyampaiannya yang memotivasi para peserta. Penilaian penyelenggara meliputi aspek program yang dilaksanakan, layanan administrasi, fasilitas penunjangnya, dan kegiatan dalam pembelajaran.

\section{DAFTAR RUJUKAN}

Amtu, O. (2013). Manajemen Pendidikan di Era Otonomi Daerah. Bandung: CV Alfabeta.

Agung, I. (2018). Jam Mengajar Guru: Tinjauan Dari Sisi Lain. Perspektif Ilmu Pendidikan, (Online), Vol. 23, No $1 \mathrm{hlm} 33$ s.d 42. https://media.neliti.com

Dariyanto, F. (2014). Manajemen Pelatihan Kurikulum 2013 bagi Guru Jenjang SMP (Studi Kasus di Pusat Pengembangan dan Pemberdayaan Pendidik dan Tenaga Kependidikan PKn dan IPS Kota Batu). Malang: Universitas Negeri Malang.

Dewi, Dantes, \& Irawan. Evaluasi Usability Pada Aspek Satisfaction Menggunakan Teknik Kuesioner Pada Sistem LMS Program Keahlian Ganda. Jurnal Pendidikan Teknologi dan Kejuruan, 15(1). https://ejournal.undiksha. ac.i d/index.php/JPTK/article/view/13028/8483

Daryanto \& Bintoro. (2014). Manajemen Diklat. Yogyakarta: Penerbit Gava Media.

Herlina, Hidayat, \& Djumena. (2017). Manajemen Pelatihan Hantaran dalam Meningkatkan Kecakapan Hidup Warga Belajar di Lembaga Kursus dan Pelatihan. Journal of Nonformal Education and Community Empowerment, 1(1). https://journal.unnes.ac.id/sju/index.php/jnfc/article/view/14758/8233

Herujito, M. Y. (2004). Dasar-Dasar Manajemen. Jakarta: PT. Gramedia Widiasarana Indonesia.

Lestari \& Ulfatin. (2016). Manajemen Pendidikan dan Pelatihan Berjenjang untuk Meningkatkan Kompetensi Guru PAUD. Jurnal Administrasi Pendidikan UM, 25(1), 79-87. http://ap.fip.um.ac.id/wp-content/ uploads/2015/05/11-Annisa-Puteri-Kusuma-Lestari.pdf

Mulyasa. (2009). Praktik Penelitian Tindakan kelas. Bandung: PT Remaja Rosdakarya.

Sonhadji, A. (2001). Manajemen Pendidikan dan Pelatihan. Malang: Universitas Negeri Malang.

Sultoni. (2016). Manajemen Diklat (Cara Menancapkan Materi Pelatihan ke dalam Memori Jangka Panjang Peserta Pelatihan dalam Rangka Meningkatkan Profesionalitas Kepala Sekolah, Pengawas, Pendidik, \& Tenaga Kependidikan). Jurnal Administrasi Pendidikan UM, Vol 25. http://ap.fip.um.ac.id/wp-content/ uploads/2015/04/25-Sultoni-Manajemen-DIKLAT.pdf

Undang-Undang Republik Indonesia Nomor 14 Tahun 2005 tentang Guru dan Dosen. Bandung: Citra Umbara.

Wijaya, Yoto, \& Suhartadi. Pengelolaan Guru Keahlian Ganda Pada Kompetensi Keahlian Teknik Kendaraan Ringan Otomotif Di SMKN 1 Singosari. JUPEDASMEN, 4(1). http://jupedasmen.com/index.php/ JUPEDASMEN/article/viewFile/202/pdf

Yoto. (1997). Manajemen Pendidikan dan Pelatihan. Malang: Departemen Pendidikan dan Kebudayaan Institut Keguruan dan Ilmu Pendidikan Malang bagian Proyek Operasi dan Perawatan Fasilitas Proyek IKIP Malang. 